\title{
Exempt Device
}

National Cancer Institute

\section{Source}

National Cancer Institute. Exempt Device. NCI Thesaurus. Code C80438.

A medical device that is exempt from FDA premarket notification requirements. 